\title{
Gandharva: Origin and Performing Arts
}

\author{
Bharat Raj Dhakal \\ School of Development and Social Engineering \\ Faculty of Humanities and Social Engineering, Pokhara University \\ Email: bdhakal79@gmail.com
}

\begin{abstract}
The prime objective of this research article is to explore the different forms of arts performed by the 'Gandharvas' along with their historicity of social and sacred religious origin towards which the mainstream Nepali society is indifferent. In the social context of Nepal, they are regarded as the musician caste. They are also treated as the so-called lower caste people, the 'dalits' and are also denied the prestigious position in the society as well as in the pages of history. Although neglected in the society as well as in the history, they have got a pious origin as mentioned in the Hindu religious scriptures and beliefs. Their performing arts and musical instruments also have the religious significance. They have made a great contribution for nation through their performing arts. But the paradox is that they have not got the true recognition in Nepali society even though they share the sacred lineage like other groups. Although they have sacred place in religion, their position is downtrodden in society.
\end{abstract}

Keywords: Gandharva, Origin, Performing arts, Recognition

\section{Introduction}

The Gandharvas are the foremost representatives of traditional Nepali folk music who travel different places to entertain people and to spread the information of some events to them. They are the musical entertainers like minstrels or troubadours. Before the time of modern means of communication like the television, the radio, the telephone etc., they were one of the major means of entertainment as well as information. Despite having such a significant contribution, they are not allowed enough space in the pages of history and the scholarly articles. The caste-based Nepali society imposed them the role of singing and dancing but did not pay attention on the exploration of their sacred religious origin and performance. In this respect, Abhi Subedi (2002) writes: "...the groups who play music and perform dances and plays are said to be ritually less pure in the caste hierarchy" (p. 121).However, there lies a great incongruity, that is their performing art is accepted in the rituals of so-called upper class. Here, Subedi (2002) further argues, "But paradoxically, the people of lower varna group having occupations which what they consider as defiling features perform music and dance at the time of the rites of passage and different ritually purifying occasions of the people of upper caste" (p. 121).

There is a great contradiction that the society separates them from social and religious activities regarding them as the 'dalits' but adopts their performing arts in their religious rituals. In this context, Prabodh Devkota (2005) argues: “... the place of Gaine seems quite sacred in Hindu religion, though the contradiction is that their position is socially decreased as untouchable group" ( $p$. 13). Hence, there are some controversies or the paradoxes regarding the social position of Gandharvas and performing arts. On the one hand, they are considered as the lower-caste and denied prestigious position in the society, and on the other hand, their performing arts (singing and dancing) have been used in the sacred rituals of the so-called upper-caste people.

It is quite necessary to know the history of any race or tribe of society for having the

Journal of Development and Social Engineering

Volume 3 | Number 1 | December 2017, 59-64

ISSN 2382-5332 @ School of Development and Social Engineering, Pokhara University 
better understanding of ourselves as well as society itself. Pointing towards the relevance of studying historicity, Chor Boon Goh (1989) mentions: "Compelling reason for studying history is that a society's identity is the product of the many individuals, forces, and events that constitute that society's past. History is society's collective memory" ( $p$. 78 ). It clarifies that a society is an amalgam of people of various races. Therefore, the identity and origin of group can be linked to the identity and origin of other group. In the like manner, O. A. Ojo (2016) maintains: "Apart from providing knowledge, history also helps to understand the present. To ignore history is to refuse to understand the present" ( $p .24)$. In this context, since Gandharvas are one of the components of our society, it becomes very crucial to delve into their historicity of origin. Their identity is associated to the identity of other races or ethnic groups. The study of their historical origin and performing arts is necessary because it provides society and the world with recognition and knowledge of our own.

It is also quite ironic that although they were the sources of entertainment and information for the people, there is lack of enough information regarding their origin and performing arts. Some of the studies have been conducted about Gandharvas focusing on the types of their songs, major residential areas, socio-economic conditions, contributions in Nepali folk literature etc. But much attention has not been given on exploring their sacred origin or lineage as well as on the performing arts. In this light, this paper digs into their origin and performing arts to foreground the unassailable religious root and performing arts so that they can be treated as the caste with pious origin, and their performance arts can get good recognition in Nepali society. For this, it involves extensive study of available literature published on different books, journals and consultation with experts, and puts forward the major findings.

\section{Origin of Gandharva}

For the enrichment of Nepali music and dance, various ethnic groups have made a great contribution. The real soul of Nepali music is preserved by many groups. One of the ethnic groups is Gandharva, also known as Gaine. This group has a great contribution for the enrichment and preservation of Nepali music. They are basically recognized as the musician caste of Nepali society just "like the singers of Serbia and African countries who sing the saga of nation, narratives of epic grandeur and stories of the communities" (Subedi, 2002, p. 127). They also sing the song of their own experiences that is full of sorrow, misery, poverty and exploitation.

Regarding the origin of Gandharvas, there are many opinions prevailing in Nepali society. But all Gandharvas agree to a common point that they have a very sacred origin, that is, they are the descendants of Gandharva Rishi. In this regard, Tribal Ethnography of Nepal (1994) writes about Gandharvas' belief of their origin which explores their affiliation with very holy rishis, the great sages. According to the book:

... Brahmaji, the creator (one of Hindu Trinity) created 4 rishis or hermits, 4 varnas or colours and 26 tribes. Among these 4 rishis, there was one Gandarva who was less cunning than his colleagues, and it is because of this susceptible nature of his that the other three rishis wanted to remove him from their group so they conspired. They gave him a leg of a cow and told him to go beg for alms uttering the word awariha. Not understanding the plot, this simple minded Gandharva Rishi did as he was told that he had defiled himself because he had used the leg of a cow and so from then on he continued his life as a beggar. Thus it is believed that Gandharva is the progenitor of the Gaine ... and simultaneously, the stringed instrument called arwajo, which they use to provide music while they sing and beg, also originated. This arwajo is supposed to symbolize cow's leg. (p. 218)

It clarifies that they have a very pious origin. Their musical instrument arwajo also has a religious significance. Their ancestral stock is joined to one of the rishis whom we worship. But it is a matter of dismay that we do not pay much attention to such pious origin.

The word 'Gandharva' is also mentioned 
in many religious scriptures of Hindu mythology and folklores. It is believed in Nepali society that Gandharvas were the musicians in heaven. Their main responsibility was to please Indra (the king of heaven) by singing and playing music. In this respect, Anindita Basu (2016) writes: "By the time the Puranas and the two epics were composed, the Apsaras and Gandharvas had become performing artists to the gods; the Apsaras are singers, dancers, and courtesans, while the Gandharvas are musicians" (Ancient History Encyclopedia). She further writes: "In the epics and the Puranas, the Apsaras and gandharvas are artists who perform at the court of Indra and other gods. They are also seen to sing and dance on other happy occasions such as births and weddings of the gods and also of humans particularly favored by the gods." There is also another story about Gandharvas and their music which has religious touch. As mentioned by her they were also mentioned in the Mahabaharata, the Hindu religious book. She writes: "The gandharvas are musicians par excellence. When Arjuna, the third Pandava, went to the heaven in search of celestial weapons, the gandharvas at Indra's court taught him singing and dancing."

Moreover, there is also another version of their origin as musicians mentioned in Hindu religious scripture. Tribal Ethnography of Nepal again writes:

While preparations were being made for the division of labour between the 4 rishis, Gandharva was engrossed in observing the dance of apsaras (heavenly dancers of extreme beauty and grace mentioned in Hindu mythological scripture), so he was given the task of singing or providing music. Therefore, it is believed that the Gaine earn their living by singing songs. (1994. P. 218)

Their profession of singing and dancing has also religious link. It was assigned by the gods. But the caste-based Nepali society regards such profession as undignified profession.

\section{Performing Arts}

Performing arts refer to different forms of arts performed individually or collectively. It is "an umbrella term for the artistic expressions that centers on the performance of an actor in a stage like setting" (Klarer, 2013, p. 141). The 'stage like setting' may refer to the theatre or the place where they perform like the roads or the houses of people. There are various types of performing arts like dance, music, drama, circus, etc.

McCarthy, in The Performing Arts in a New Era defines it from a broad perspective: "By performing arts, we mean theatre, music, opera, and dance, from the traditional "high arts" to the popular arts, including live arts performed in all venues and non-live arts through all forms of mass media: CDs and other recordings, radio, video, television and the Internet" (2001, p. 5). It shows that the mode of production of performing arts is multiple with immense potentiality. There are various factors that play the significant role on shaping the future of performing arts. The most important factor is how it is consumed. For this, the role public involvement in production and reception becomes crucial. In this regard, the author further argue: "Some people may be directly involved in a "hands-on" way by playing an instrument or singing in a choir. For others, consumptions means attending a live performance" (2001, p. 17).

In every performing art, there lies a great role of the artist who possesses the guiding or the controlling power. Clarifying the role of artist, Gregory Battock and Robert Nickas (1984) write, “... performance was independent of current trends and traditional forms, and this independence guaranteed, for a time, that performance art would remain controlled and guides by the artists who originated the form" ( $p .6)$. Along with the artist, there is also a great role of audience without whom the art becomes insignificant. Focusing on the important role of audience in the performing arts, Tero Nauha (1993) states:

Performance arts is not a skilled technique but takes place in between the one who is doing and the ones who are observing it. Yes, performance art needs an audience, and as such it is similar to other live activities such as stage driving: if you tried to do without an audience or have a rather reluctant one, the result is tragic or at least comic. The performance is in relationship, but more significantly it is an action. (1993, p. 64) 
It clarifies that the real significance of any performing arts lies in combination of the artist and at least an audience. If there is no audience, there is also no value of art.

Rather than teaching, performance art is "a mimetic learning process" (Nauha, 1993, p. 61). It transmitted from one generation to other generation in which observation and imitation play a vital role.

\section{Gandharvs' Performing Arts}

The only survival means of the Gandharvas are their typical forms of arts; their song, music and dance. They are the sources of entertainment as well as information in Nepali societies. They have also made a great contribution even in the unification campaign of Prithvi Narayan Shah. Despite having such a glorious background, political contribution and social significance, they live a miserable life because their occupation of singing, dancing and music playing are on the brink of extinction.

\section{Singing}

The main performing art of Gandharvas is singing. They are, like troubadours of Europe, visit the houses of people and sing for livelihood. On the one hand, they try to sustain life through singing, and on the other hand, this activity becomes a milestone of preserving the folklores. In this way, the credit for the preservation and propagation of Nepali folklores goes mainly to Gandharvas. They possess the real genesis of Nepali folk music who entertain people with their sweet rustic melodies. Therefore, they are the integral part of Nepali folk music. Highlighting the importance at their singing, Abhi Subedi (2002) maintains: "The Gaines are basically singers who visit people's houses and sing songs about historical incidents, love, faith, and battles. Their presentation and style of singing evoke social drama, the stage of which is the mind of every listener" (p. 27). It clarifies that they sing on the varieties of subjects which reflect the true picture of Nepali mind and society.

There is one misconception about the Gandharva songs that people take all songs sung by them as the Gandharva song. Not all the songs sung by them should be understood as Gandharva songs. Clarifying this, Kusumakar Neupane (2065) in his Gandharvako Loksahitya: Nirantarata ra Pariwartan, says: "Gandharvas have been singing typical songs of their own race along with other songs. Therefore, not all the songs can be regarded as Gandharvas' songs" (My Translation, p. 88).

Regarding the contribution of Gandharvas, only few names are found in the pages of history of Nepal. However, their contribution is great. Ram Sharan Darnal, in this context, gives the example of Mani Ram Gaine who was employed by Prithvi Narayan Shah for the unification of Nepal as a singer to arouse courage, enthusiasm and bravery upon soldiers. Here, Darnal (2002) notes: "Mani Ram Gaine was the historical figure during the regime of Prithvi Narayan Shah. Unfortunately, written history does not much talk about him" (Dalits of Nepal: Issues and Challenges $p$. 143). During the time of medieval Kings they were also employed as poet-singer. According to Macdonald (1975), in medieval king's court, they used to work as bards.

They travel around the villages singing and playing sarangi. Not only they perform the task of entertaining people with sweet folk music, they also spread news of public interests through songs much in common to Europe's minstrels. It is, therefore, said in Nepali society that "the child of Gaine and Nyauli (a bird) don't stay at the same place forever" (Pandey, 2063, p. 12).This statement also indicates that they are the travelers who visit houses of people to sing.

They sing various genres of songs. According to Kusumakar Nepane (2065), their major genres of songs are Karkha, Raga, Mangala, Ghatana Geet, Gatha, Malsiri, Nirguna, Jhyaure, Bhajana etc (Bhrikuti: Samalochanatmak Ewam Anusandhanatmak Sahityik-Sanskritik Traimasik). In other words, "their narratives are either based on the local myths like Pashupati, Gorakhnath or the legends related to the historical personalities which include kings, prime ministers and famous fighters of country" (Divasa, Regmi \& Nepal, 2007, p. 12). They sing these varieties of songs according to the situation and occasion.

But, unfortunately, since many Gandharvas have begun to involve on other 
professions, they have been dropping out their traditional profession of singing. In this regard, Kusumakar Neupane (2064), in his Gandharvaka Pradarshankari Lokakala: Nirantarata ra Pariwartan, remarks: "The number of Gandharvas sustaining life through performing the art of singing has become less. Educated and other Gandharvas who have adopted other professions don't show interest on sarangi playing" (My Translation, p. 80). Since their profession is not considered prestigious today and it cannot fulfill their basic needs, many Gandhavas have begun to adopt other professions which can make their livelihood possible. Pointing towards the possible consequences of this situation, Neupane (2064) states, ". . Because of such distraction on the art of singing, the hope of preservation of Gandharvas' traditional art of singing cannot be fulfilled from the latter generation of Gandharvas" (My Translation, 2064, p. 80).

\section{Music Playing}

Not only in singing, Gandharvas are equally expert in playing the music. Their main musical instruments are 'sarangi' and 'arwajo'. Sarangi is a four stringed instrument carved from light wood. It is played with a bow made from the hair of horse's tail. Sometimes we can also see nylon strings in the bow. They always carry it with them wherever they go. This musical instrument produces such a sweet sound through which each and everyone can feel themselves spellbound. Regarding the origin of sarangi, Ram Sharan Darnal (2061), in his book Nepali Baja, writes: "since it produces the sweet sound like that of a Sarang bird it is called sarangi" (My Translation, p. 27). According to another version of idea, sarangi is the combination of two words: sa and rangi where sa refers to the first note of music and rangi denotes the colorful and entertaining moments. The combination of those two words gives us the meaning that it is a musical instrument that produces various rotes of music to entertain the audience. Gandharvas regard it 'female' musical instrument since it produces mild and soft sound.

Arwajo is another musical instrument popular in Gandharva community. It is also their religious musical instrument. According to Ram Sharan Darnal (2061), this musical instrument originated long before the origin of sarangi. He also attributes to its religious origin. He states: "It is a religious belief that Brahmaji provided them this Arwajo for earning their livelihood in the beginning. Therefore there is carving of human face at the head of this instrument" (2061, p. 9). It is larger than the sarangi just like the guitar having four strings. It is also played as the guitar is played. Gandharvas also regard it as a gift from Lord Bishnu. Since it produces harsh sound, they consider it as the 'male' musical instrument.

These musical instruments are facing challenges to compete with the modern luxurious musical instruments. The inventions of sophisticated instruments have been replacing these traditional instruments day by day. In the modern technologically advanced world, it has become a great challenge to preserve such traditional musical instruments.

\section{Dancing}

Apart from singing and music playing, Gandharvas have another form of performing art, that is, dancing. Kusumakar Nepane, regarding their dance, writes that the major dances for which Gandharvas are famous are Tarbare Nritya (Sword Dance), Jaimalpatta Nritya and Ratyauli Nritya. In Tarbare Nritya, they dance taking sword in a hand and present the scene of bloodshed. This dance reflects the scene of war. In 'Jaimalpatta Nritya', they dance in group playing four sarangis, two arwajos, two madals and two mujuras. Furthermore, Ratyauli Nritya is performed in marriage ceremony especially by women.

\section{Conclusion}

Although regarded as untouchable and treated as marginalized in Nepali mainstream society, the ethnological study of Gandharva shows that they have a very pious lineage. Their affiliation to gods, goddesses, rishis and apsaras has been mentioned in many religious scriptures. Somewhere they were mentioned as entertainers whereas in some books they were regarded as the music and dance teachers to gods. Not only this, in some religious writings, they were acknowledged 
as the descendants of rishis. Their performing arts also have religious associations. According to those writings, their tasks of singing, playing music and dancing were also considered holy and prestigious too.

Unfortunately, such affiliations have been overshadowed in later time, especially by caste-based Nepali tradition. In contemporary society, there is no genuine recognition of this ethnic group which is inspired by psychological as well as cultural aspects to accommodate and resist the distinction. Now, it is time of revision and finding out the similarities out of seemingly dissimilarities. Ultimately, this revision includes the reexamination of artificial distinctions, especially created by caste-based belief, of various groups by locating all in historical and cultural contexts. This would create similarities among different groups, which is the real need for a harmonious society. The act of erasing and altering their long-rooted performing art should be avoided as they exist via performance. There is a need for the protection of the folk practices arousing the awareness against social malpractices and discrimination.

Modern society is a fusion various groups of people having their different traditions. They have to live creating a harmonious social environment. The performing arts of the Gandharva through their musical instruments can contribute a lot to bring harmony among such groups of people in the same larger society. So, their musical instruments and their music must be preserved from the modern point of view. Those are harmonious musical instruments that sensibly bind all to live in harmonious way. One of the means of providing good recognition or respect to them is to highlight the story of their origin and honoring their performing arts.

\section{References}

Basu, A. (2016). Apsaras and Gandharvas. Ancitent History Encyclopedia. Retrieved from https://www.ancient.eu/Apsaras_ and_Gandharvas/

Battock, G \& Nickas, R. (1984). [Introduction]. In The art of performance: A critical anthology. (pp. 5-13). New York: E.P. Dutton. Inc.
Darnal, R. S. (2002). Dalit, music and society. In P.M. Devkota (Ed.), Dalits of Nepal: Issues and challenges. (pp. 139-145). Lalitpur: FEDO.

- - (2061). Nepali baja. Kahmandu: Ratna Pustak Bhandar.

Devkota, P. (2005). Nepali Troubadours. Neplai Folslore Society Newsletter, 1(1), 13-15.

Divasa, T., Regmī, C., \& Nepal, B. (2007). The intangible cultural heritage of Nepal: Future directions. Kathmandu: UNESCO Office.

Gautama, R., \& Thapa-Magar, A. K. (1994). Gaine. Tribal ethnography of Nepal (Vol. 2). (pp. 217-224). Delhi: Book Faith India.

Goh, C. B. (1989). The relevance of history to our lives today. Teaching and Learning, 10(1). (pp. 75-82). Singapore: Institute of Education.

Klarer, M. (2013). An introduction to literary studies. London: Routledge.

Macdonald, A. W. (1975). The Gaine of Nepal. In Essays on the Ethnology of Nepal and South Asia. Kathmandu: Ratna Pustak Bhandar.

McCarthy, K. F. (2001). The performing arts in a new era. United States: Rand Corporation.

Nauha, T. (1993). Performance art can't be taught. In P. Porkola (Ed), Performance artist's workbook: on teaching and learning performance art: essays and exercises. (pp. 97-109). Finland: The Theatre Academy, University of Helsinki

Neupane, K. (2064). Gandharvaka pradarshankari lokakala: Nirantarata ra pariwartan." Janapragyamanch. Pokhara: JMCU, pp. 76-82.

- - -. (2065). Gandharvako loksahitya: Nirantarata ra pariwartan." Bhrikuti: Samalochanatmak Ewam Anusandhanatmak Sahityik-Sanskritik Traimasik. Kathmandu: Bhrikuti Academic Publications, 87-96.

Ojo, 0.A. (2016). Introduction to Historiography. Nigeria: University of Ibandan Distance Learning Centre.

Pandey, M. (2063). Gaine. Nepalka Dalitharu. Kathmandu: Pairavi Prakashan.

Subedi, A. (2002). Dalits and performing arts. Dalits of Nepal: Issues and challenges. (pp. 119-131). Lalitpur: FEDO. 